property $^{8}$ of Rebels as well as all other acts by him done to crush Rebellion in the South and toryism ${ }^{9}$ in the North

Henry McCarthy"

September of 1862, gave Southerners the alternative of ceasing their rebellion by January $1,-1863$ or to suffer economic loss through the freeing of their slaves.

${ }^{8}$ Slaves, at this time, were regarded as property. The Dred Scott decision, issued March 7, 1857, legally supported this idea by stating that a slave, whether living in a.slave.state or a free state, was the property of his owner.

"According to Mitford Mathews' A Dictionary of Americanisms on Historical Principles, a tory is "a person regarded as disloyal; a traitor." Therefore, "toryism in the North" refers to the Northerners disloyal to the Union. This term is somewhat confusing in that there were more popular words used during the Civil War to identify Southern sympathizing Northerners, such as "Copperheads" and "Doughfaces".

Reprint from: Dubuque Times-Journal, October. 29, 1922

\title{
IOWA IS HOME OF LONE SURVIVOR OF "THE GALLANT SIX HUNDRED"
}

Cedar Rapids, Ia., Oct. 28,-Ellis Cutting, sole survivor of the famous "Charge of the Light Brigade," rode unscathed through that gallant but futile action-to be hurt by a snow plow near here.

Today, 68 years after the immortal execution of blundered orders, Cutting, 85, is alive and alert. He recalls as though it were yesterday the charge at Balaklava, in which he participated as a youth of 17 , the charge of Tennyson's poem immortalized.

With the Crimean war in progress-Britain and France allied with Turkey against Russia-the Russians attacked the allies at Balaklava Oct. 25, 1854, hoping to cut allied com: munications.

The "Heavy Brigade" of British cavalry made a furious charge, swept back the attackers and drove them back behind their own artillery. 


\section{BLUNDER APPARENT}

The "Light Brigade," commanded by Lord Cardigan, then received orders to charge these cannon and prevent their removal. For cavalry, mounted and armed with lances and sabers, to charge cannon was plainly suicidal. Lord Cardigan read the order, questioned the aide delivering it, the latter, Captain Nolan, waved his arm down the valley toward the Russian cannon.

"Forward, the Light Brigade!" commanded Lord Raglan. Unquestioningly, the 600 troopers, galloped forward, guidons flying, sabers flashing.

Beyond the allied lines, Russ artillery fired point blank from three sides into the gallant horsemen. Captain Nolan, bearer of the note to charge, suddenly dashes across the front of the chargers, possibly to swerve the troops from the death trap. A shell made him the first to fall.

\section{GUNS ARE TAKEN}

Straight at the enemy guns out in front rode Cardigan's command. The numbers dwindled rapidly as converged cannon fire swept them.

The guns were reached, silenced. Small parties even attacked the cavalry behind. But a battle against such overwhelming odds could only end in annihilation. Other. cavalry arrived in time to hold the ground won by the Light Brigade.

Most historians say a third of the Light Brigade survived. Cutting, though, says only six came out alive. Lord Cardigan was one of these.

"I can't describe it, it's beyond me," says Cutting. "We were swept through that hell of fire and death hearing nothing, knowing nothing, feeling nothing but a desire to reach the Russians." him first."

"Everyone hoped to pick a man. All I thought was to get

\section{ACTIVE TODAY}

"Instead of rushing in cavalry, Lord Raglan ought to 
have ordered an infantry maneuver. That would have saved hundreds of brave boys."

Cutting later served in the British army in Indian mutinies, in the Lucknow siege in Egypt and in South Africa. The only wound he received was a bayonet thrust in one foot.

Coming to America, he became a fireman on what is now the Rock Island, was promoted to engineer six months later and served until pensioned in 1910.

Forty years ago, he was thrown 60 feet by a rotary snow plow, and sustained several broken bones. Aside from that, he has never been hurt in railroading.

"Foin Tim" Cutting, the railroaders call him all over the Rock Island system. He reads newspapers without his glasses, and he walks two miles or more every time he goes downtown from his home.

Reprint from: the Sunday Times, Spencer, Iowa, February 15, 1970 , page 5.

Early Days Near Royal

\section{KILLED IN IOWA, HANGED IN WEST}

by Don Buchan

Royal-Like all towns Royal has had it's (sic) tragedy... Billy the Kid, they say, killed 21 men before he was 21 years old. Happy Herman, alias Charlie Craig, who came here from Alton, Ill., killed his first man at the age of 15 , and while only one other murder was actually laid at his door, he may have come closer to Billy's record than the known facts disclose.

It was in March, 1917, when such words as Kaiser, Hun, flapper, and faming youth were on everyone's lips. Mr. and Mrs. Harry Peterson, newly married, lived on a farm near Royal and had just purchased a new Ford automobile.

As Mrs. Peterson busied herself in the kitchen, likely thinking that spring would soon come and the mountains of ice and snow would melt away and they could visit neighbors in their new Ford, she heard the dull boom of a shotgun. Perhaps she thought Harry or the hired man, Happy Herman, 
Copyright of Annals of Iowa is the property of State of Iowa, by \& through the State Historical Society of Iowa and its content may not be copied or emailed to multiple sites or posted to a listserv without the copyright holder's express written permission. However, users may print, download, or email articles for individual use. 